\title{
The Effect of Polyamines and Silver Thiosulphate on Micropropagation of Date Palm Followed by Genetic Stability Assessment
}

Ahmed M.W Al-Mayahi ( $\sim$ hng_1988@yahoo.com )

University of Basrah https://orcid.org/0000-0002-1054-0233

\section{Research Article}

Keywords: Shoot regeneration, Multiplication, Rooting, Acclimatization, RAPD

Posted Date: January 11th, 2022

DOI: https://doi.org/10.21203/rs.3.rs-1175104/v1

License: (c) (i) This work is licensed under a Creative Commons Attribution 4.0 International License. Read Full License 


\section{Abstract}

There are some limitations in the practical applications of in vitro date palm tissue culture, such as low multiplication efficiency, low rooting rate, and high mortality experienced by in vitro raised plantlets during laboratory to soil transfer. This study's objective was to investigate the effect of the two types of polyamines (putrescine "PUT" and spermidine" SPD") in combination with silver thiosulfate (STS) on the growth and development and genetic stability of cultures of Quntar cultivar. Media supplemented with $75 \mathrm{mg} \mathrm{L}^{-1}$ SPD in combination with $10 \mathrm{mgL}^{-1}$ STS gave the highest percentage of callus producing buds (83.34\%) and average bud formation (16.3) per jar. The addition of PUT and STS to the medium was most effective in root formation and the number of roots per shoot, where the best result $91.67 \%$ and 6.37 roots per shoot, respectively, were obtained using $75 \mathrm{mgL}^{-1}$ PUT and $10 \mathrm{mgL}^{-1}$ STS, resulting in fast-growing plantlets during acclimatization phase, reaching $90 \%$ of plant survival. The genetic fidelity assessment of plants derived from micropropagation was confirmed by RAPD analysis. Four operon primers were used, and all of them showed amplified unambiguous (OPA02, OPC-04, OPD-07, and OPE-15). All generated bands were monomorphic and had no variation among the tissue culture-derived plants tested. Accordingly, these results indicate that adding polyamines and silver thiosulfate to the nutrient medium of date palm cv. Quntar is beneficial in improving shoot organogenesis, rooting, and production of genetically stable date palm plants.

\section{Introduction}

The date palm (Phoenix dactylifera L.), a tree of the palm family (Arecaceae) cultivated for its sweet, edible fruits. The date palm has been prized from the earliest times and may have originated in ancient Mesopotamia, now known as Iraq. The date palm can be propagated either from seeds or from offshoots. When plants are grown from seeds, about half of the palms will be males, which can be identified only when flowering. Moreover, the plants obtained through seeds are genetically heterogeneous. Consequently, for uniformity of the orchards, date palms are propagated through offshoots only. Due to the little offshoots that trees produce, the date palm is one case that requires serious attention for rapid vegetative propagation. Micropropagation technology has overcome these problems and provides uniform and good quality planting material to establish large-scale plantations (Ibrahim et al., 2013; Al-Mayahi et al., 2018; AlMayahi and Ali., 2021). Micropropagation contributes to plant growth and development by modifying biochemical and physical media (Al-Mayahi, 2019; 2020). Organogenesis is one of the growth pathways through which buds can be stimulated to differentiation. Studies have shown that successful organogenesis can be achieved through the appropriate establishment of culture medium components, appropriate explant selection, and control of the physical environment (Thorpe, 2007). It is clear from the literature that polyamines have an important role in plant tissue culture, as their use has expanded in recent years, especially in stimulating and multiplying shoots. Polyamines are lowmolecular-weight organic cations essential for tissue growth and development due to their role in cell proliferation, signal transduction, and protein synthesis (Rakesh et al. 2021). Studies have shown that adding polyamines to culture media can enhance shoot growth, callus induction, and root regeneration (Tang and Newton, 2005; Thiruvengadam et al., 2012). Chae (2016) reported enhanced plant regeneration of Echinacea angustifolia DC plants in vitro in the presence of polyamines. Kiełkowska and Adamus, (2021) reported that PUT and SPD had a beneficial effect on the mitotic activity of cultured cells, which further affected the plant regeneration process. In vitro propagation has limitations, especially when the accumulation of ethylene in culture containers is severe and the genotypes exhibit sensibility to this phytohormone (levinsh et al., 2000). Studies have shown that externally applied polyamines can promote ethylene production in the culture medium. Thus it is likely to affect growth and development in such systems. Ethylene accumulation in culture vessels under in vitro propagation systems appears to be a major problem in date palm regeneration studies. Ethylene inhibitors, including silver thiosulfate (STS) affect ethylene activity, preventing or reducing sensitivity and negatively affecting plant tissues (Wang et al., 2002). Meanwhile, ethylene inhibitors can be 
used as a stimulator to promote callus induction and shoot regeneration (Al-Mayahi., 2010). Roh et al. (2012) also reported that STS was more effective than $\mathrm{AgNO}_{3}$ on shoot regeneration from cotyledon and hypocotyl explants of $B$. napus. Somatic clonal variations may occur mostly as a result of stresses to the plantlets under laboratory conditions. Suggesting visual phenotypic evaluation may not be sufficient for characterizing the in vitro plants. Hence, an astringent quality test in terms of genetic similarity of the tissue culture-raised plants becomes necessary. Out of various molecular markers used to evaluate in vitro regenerated plants' genetic fidelity, RAPD is one of the most simple, quick and cost-effective methods and requires only small amounts of DNA (Chaudhary et al., 2015). Srivashtav et al. [17] suggested that RAPD markers are more efficient than ISSR for assessing genetic variation in date palms. Molecular markers RAPD is reliable in monitoring variability at the DNA level in plants. Several researchers used RAPD technique to examine genetic variability. It is an efficient and reliable technique for screening true to types of nature of tissue culture-derived plants (Moghaieb et al.,2011; Deviet al.,2013; Chaudhary et al., 2015). Despite the benefits of date palm propagation in vitro, multiplication and rooting rates are low, and high mortality during acclimatization. Therefore, this research aimed to evaluate the effects of two types of polyamines (putrescine "PUT" and spermidine" SPD") in combination with silver thiosulfate (STS) on multiplication shoots, rooting, acclimatization, and genetic stability; RAPD indicators were used to determine genetic stability of in vitro multiplied materials to determine the protocol effectiveness.

\section{Materials And Methods}

The experiments of this study were carried out in the date palm micropropagation laboratory for Date Palm Research Center at Basra University, Basra, Iraq.

Offshoots of Quntar cv.(2-3 years old) were chosen and detached from the mother palm (Fig.1a). Offshoots were dissected acropetally until the apical buds appeared (Fig. 1b). The apical buds were sectioned longitudinally into four parts. In order to induce callus induction, explants were cultured on the MS basal medium (Murashige and Skoog,1962). Media was prepared from MS medium salts $\left(4.43 \mathrm{~g} \mathrm{~L}^{-1}\right)$ mixture containing the macronutrients and micronutrients. It was combined with Gamborg's vitamins and equipped with $3 \mathrm{mg} \mathrm{L}^{-1} 6$ - (dimethylallyl amino) purine (2iP), $30 \mathrm{mgL}^{-1}$, naphthalene acetic acid (NAA), $1.5 \mathrm{~g} \mathrm{~L}^{-1}$ activated charcoal, and solidified with Agar-Agar at $7.0 \mathrm{~g} \mathrm{~L}^{-1}$., supplemented (Fig. 1C). Cultures were incubated under complete darkness at $27 \pm 2{ }^{\circ} \mathrm{C}$. Cultures were transferred to new media, with the same composition after every 6 weeks interval until the callus had an induction (Fig. 1d). For callus multiplication, it was transferred to jars containing $25 \mathrm{ml}$ of the MS medium, with Gamborg's vitamins and supplemented with $0.5 \mathrm{~g} \mathrm{~L}^{-1}$ activated charcoal, with the addition of NAA at $6 \mathrm{mg} \mathrm{L}^{-1}$ and 2iP at $2 \mathrm{mg} \mathrm{L}^{-1}$. To study the effects of polyamine type on the multiplication of buds, the callus was divided and subcultured on organogenesis media equipped as mentioned above, except for the growth regulators concentrations $1 \mathrm{mg} \mathrm{L}^{-1}$ (NAA) and $3.0 \mathrm{mg}$ $\mathrm{L}^{-1}(2 \mathrm{iP})$. It was also supplemented with Putrescine (PUT) and spermidine (SPD) in concentrations $(0.0,25,75$, and 150 $\left.\mathrm{mg} \mathrm{L}^{-1}\right)$. The $\mathrm{pH}$ of the culture media was adjusted to 5.7 with $0.1 \mathrm{~mol} \mathrm{~L}^{-1} \mathrm{NaOH}$ or $\mathrm{HCl}$ before adding agar. Media were dispensed into culture jars. The culture's jars were sterilized with media by autoclaving at $121^{\circ} \mathrm{C}$ and pressure of $1.04 \mathrm{~kg} \mathrm{~cm}^{-2}$ for $20 \mathrm{~min}$. All the cultures were incubated at $27 \pm 2{ }^{\circ} \mathrm{C}$ and irradiated for $16 \mathrm{~h}$ with a diffuse light provided by daylight fluorescent lamps. Based on the result of our previous experiment, the appropriate type of polyamine was selected in combination with silver thiosulphate (STS). To study their effects on buds regeneration and changes in phytochemicals. MS medium was modified at four concentrations of $\operatorname{SPD}\left(0.0,25,75\right.$, and $\left.150 \mathrm{mg} \mathrm{L}^{-1}\right)$ in combination with silver thiosulfate (STS) at four concentrations $\left(0,5,10\right.$, and $\left.15 \mathrm{mg} \mathrm{L}^{-1}\right)$. Data on the percentage of bud induction and bud number per jar were taken after 12 weeks of culturing callus on the organogenesis media. Treatments were consisted of 12 media, as shown in Table 1 
Optimization of rooting and plant acclimatization Clusters with no visible signs of roots formation was collected in the elongation stage; typical shoots were separated individually and cultured on a rooting MS medium. It was combined with Gamborg's vitamins and supplemented with $30 \mathrm{mg} \mathrm{L}^{-1}$ sucrose, $7 \mathrm{mg} \mathrm{L}^{-1}$ agar $0.5 \mathrm{mg} \mathrm{L}^{-1} \mathrm{NAA}$, and $0.5 \mathrm{~g} \mathrm{~L}^{-1}$ activated. The media were supplemented with two types of polyamines PUT and SPD in concentrations $(0.0,25,75$ and $\left.150 \mathrm{mg} \mathrm{L}^{-1}\right)$. The cultures were maintained at $16 \mathrm{~h}$ photoperiod at $25 \pm 1 \circ \mathrm{C}$ and irradiance of $13.5 \mu \mathrm{mol} \mathrm{m} \mathrm{m}^{-2} \mathrm{~s}^{-1}$ provided by cool white fluorescent tubes. Each treatment included 12 replicated jars. The percentage of root induction and root number per shoot were evaluated 6 weeks after the inoculation of shoots on the media. Based on the result of our previous experiment, the appropriate type of polyamine was selected in combination with STS. To study their effects on the percentage of root induction and root number per shoot were evaluated 6 weeks after the inoculation of shoots on the media. MS medium was modified at four concentrations of PUT $\left(0.0,25,75\right.$, and $\left.150 \mathrm{mg} \mathrm{L}^{-1}\right)$ in combination with silver thiosulfate (STS) at four concentrations $\left(0.0,5,10\right.$, and $\left.15 \mathrm{mg} \mathrm{L}^{-1}\right)$. The percentage of root induction and root number per shoot were evaluated 6 weeks after the inoculation of shoots on the media. Treatments were consisted of 12 media, as shown in Table 2.

Acclimatization Stage. For acclimatization, well-developed plantlets were gently washed with tap water to remove the remnants of agar. Then, the plantlets were washed with distilled water and treated with fungicide (Benlet $500 \mathrm{mg} \mathrm{L}^{-1}$ ) for 20 min and transferred to plastic pots containing autoclaved a mixture of peat moss and perlite (2:1). Maintaining the plantlets at high humidity for the first few days following transplanting is critical. Cover the plants with glass bottles to maintain humidity. After six weeks, glass bottles were removed plants gradually were irrigated with $1 / 2$ strength MS salts.

After eight weeks calculated the percentage for plantlets acclimated as follows:

Number of plantlets acclimated

\section{Percentage of plantlets acclimated $=------7 \times 100$ \\ The total number of plantlets}

\section{Genetic stability among regenerated date palm plantlets}

In order to study the genetic similarities, several regenerated plantlets were analyzed at the molecular levels using RAPD analysis

\section{RAPD analysis}

Total genomic deoxyribonucleic acid (DNA) was isolated from regenerated date palm plantlets using the CTAB method described in Rogers and Bendich (1985). Polymerase chain reaction (PCR) reactions were conducted using a set of four arbitrary 4-mer primers (Operon Technology, Inc., Alameda, CA, USA). These primers and their sequences are presented in Table 3.

\section{The PCR mixture}

The reaction mixture $(20 \mu \mathrm{l})$ contained $10 \mathrm{ng}$ DNA, $200 \mu \mathrm{M}$ deoxynucleotide triphosphates (dNTPs), $1 \mu \mathrm{M}$ primer, 0.5 units of Red Hot Taq polymerase (AB-gene Housse, UK) and 10-X Taq polymerase buffer (AB-gene Housse, UK). For DNA amplification, a Perkin Elmer thermal cycler (2720) programmed as follow: Denaturing: $95^{\circ} \mathrm{C}$ for 5 min $94^{\circ} \mathrm{C}$ for $0.45 \mathrm{~min}$. Then annealing (35cycles) $35^{\circ} \mathrm{C}$ for $1 \mathrm{~min}$. This is followed by $72^{\circ} \mathrm{C}$ for $1 \mathrm{~min}$ and $30 \mathrm{~s}$ and finally Extension: at $72^{\circ} \mathrm{C}$ for $7 \mathrm{~min}$ (Adawy et al., 2004). The amplification products were separated in $1 \%(\mathrm{w} / \mathrm{v}$ ) agarose gel in $1 \mathrm{X}$ Tris/Borate/Ethylenediaminetetraacetic_acid (TBE) buffer and visualized by staining with ethidium bromide. The 
reproducibility of DNA profiles was determined by replicating all RAPD reactions at least three times using DNA markers. The primers were evaluated from a wise pair comparison for the proportion of shared bands amplified (Nei, 1978). The similarity coefficient was calculated by using the statistical software package STATISTICA-SPSS (Stat Soft Inc).

\section{Experimental design and statistical analysis}

The experiments were carried out using a completely randomized design(CRD). Data were analyzed using variance (ANOVA) analysis using Statistical Package for Social Sciences (SPSS) software version 20. Treatment means were compared using the least significant difference (LSD) at the $\mathrm{P}<0.05$ level

\section{Results}

\section{Shoot induction and multiplication}

From the results of our current study, it was found that the two types of polyamines (PUT and SPD) worked well for the regeneration of date palm cv Quntar (Table 4). The highest response percentage of callus tissue cultures producing buds with the highest number of shoots was obtained at $75 \mathrm{mgL}^{-1}$ for each studied polyamines compound. Without polyamines, the control medium recorded the lowest response with the lowest number of buds $(26.67 \%$; 2.75$)$, respectively. Results showed that when SPD was added to the culture medium, the highest response percentage of callus tissue cultures producing buds with the highest number of shoots was recorded at $\left(75 \mathrm{mgL}^{-1}\right)$ reached $(73.34$ and 9.18), respectively.

From the results of our current study (Table 5), it was evidenced that the response percentage of callus tissue cultures producing buds with the number of buds increased with increasing concentration of polyamines used up to $75 \mathrm{mgL}^{-1}$ and then decreased. The percentage of callus producing shoots and the number of shoots per jar also increased with the increase STS concentrations from $0 \mathrm{mg} \mathrm{L}^{-1}$ to $10 \mathrm{mgL}^{-1}$ proportional to the concentration in the medium, but after that decreased with increasing STS concentrations. The combination between SPD and STS application had the highest response percentage and number of shoots, compared with treatments with no additives or one additive alone (Tables 4and 5). The highest response percentage and numbers of shoots ( $83.3 \%$ and 16.3 ) were obtained on the media supplemented with $75 \mathrm{mg} \mathrm{L}^{-1}$ SPD and $10 \mathrm{mg} \mathrm{L}^{-1}$ STS, respectively (Fig.2g).

\section{Rooting and plantlets induction}

From the data presented in Table (6), adding two types of polyamines separately at the studied concentrations to the nutrient medium improved the percentage of rooting and the number of roots cultured for date palm cv Quntar. The highest significant value of percentage of rooting and the number of roots/shoot was obtained at $\left(75 \mathrm{mgL}^{-1}\right)$ for each polyamine compound studied. The data showed that when PUT was added to the culture medium, the highest significant value was recorded, increasing the percentage of rooting and the number of roots/ shoot (80\% and 5.75), respectively. A high concentration of $150 \mathrm{mg} \mathrm{L}^{-1}$ PAs positively affects the length of roots as compared with the other treatments

The combination between PUT and STS application had the highest percentage of rooting and the number of roots/shoot, compared with treatments with no additives or one additive alone (Tables 6 and 7). The highest percentage of rooting and the number of roots/shoot (91,67 and 6.37) were obtained on the media supplemented with $75 \mathrm{mg} \mathrm{L}^{-1}$ PUT and $10 \mathrm{mg} \mathrm{L}^{-1}$ STS, respectively (Fig.3). While the high concentration of $150 \mathrm{mg} \mathrm{L}^{-1}$ of PAs with all concentrations of STS positively affects root length compared to other treatments. 


\section{Acclimatization}

The obtained data (Fig. 4) showed that adding polyamines PUT to silver thiosulfate (STS) improved the survival percentage. Maximum survivability was noticed for plants cultured in media containing both 75 PUT +10 STS (Fig.5), followed by plants cultured in media containing 75 PUT +5 STS. The media did not contain STS, and the addition of PUT or STS at high concentrations was not suitable for date palm acclimation, where the survival percentage was low.

\section{RAPD analysis}

In this study, we regenerated plants from callus tissues with polyamine and silver thiosulfate STS; hence it becomes necessary to check the genetic stability of the regenerated plant. Random amplified polymorphic DNA markers (RAPD) were used in the present study under the influence of different treatments (Fig6). The results showed the genetic stability of in vitro propagated plants. The PCR amplification results showed a monomeric band in both the in vitro derived date palm plants and the mother plants of all primer pairs tested. RAPD analysis micropropagated plant $(P$. dactylifera L cv. Quntar) indicated a profile similar to that of the control group that clearly showed the genetic stability of those plants (Fig. 6) and the fidelity of the in vitro propagation protocol to produce true-to-type date palm plants, indicating that the use of polyamine and STS during micropropagation phases caused no variation in the plants of this date palm cv. Quntar.

\section{Discussion}

Although shoot induction occurs, shoot number, elongation, and rooting are challenging in date palm (Al-Mayahi, 2021a). Shoot organogenesis depends on many factors, such as culture medium composition and culture conditions (Al-Mayahi,2016; Al-Mayahi et al.,2020; Al-Mayahi, 2021b). This study evaluated the effect of medium composition on shoot organogenesis. Our experiment indicates that using PAs in combination with STS plays a synergistic role in promoting multiple shoot formation from callus tissues of date palm in vitro. SPD with STS increased the regeneration frequency of date palm shoots in vitro.

The addition of polyamines to the culture medium was influential in the regeneration of shoots. The best type and concentration of polyamines used was SPD at $75 \mathrm{mgL}^{-1}$. PAs play a major role in cell division, plant growth, and development (Mattoo et al., 2010). It has been shown that PAs interact with plant hormones, act as PGR substances or secondary hormonal messengers, and as carbon and nitrogen storage in culture tissues (Couée et al, 2004). Furthermore, PAs carry amino groups capable of interacting with macromolecules, such as nucleic acids, proteins, phospholipids, and cell wall components, and may have different effects on the culture medium (Takahashi and Kakei, 2010; Tiburcio et al., 2014). Shoots multiplication helps increase the number of plantlets achieved through hormonal combination and Pas (Dey et al. 2019). The positive effect of polyamines on shoot regeneration can be attributed to their stimulatory effect on cell division (Bais and Ravishankar, 2002). It has been suggested that regeneration and differentiation can be significantly improved by applying putrescine in date palm (Muhsen et al., 2020). It has been advocated that shoot regeneration and differentiation can be significantly improved by using PAs with ethylene inhibitors (Park et al.,2012). In the present study, the influence of ethylene inhibitor STS on in vitro culture of date palm was investigated. According to the results obtained, using STS in culture media can enhance the ability of date palm callus tissues to give the highest response percentage of shoots and shoot numbers. Silver thiosulphate is a suitable candidate for use in Quntar cultivar for the regeneration and multiplication of shoots and the rooting of plants. Although this response depends on the concentration of STS used. The highest percentage of callus producing buds and shoot number was achieved on media supplemented with $10 \mathrm{mgl}^{-1}$ STS. High concentrations of STS do not have an important positive role in bud production. However, a medium without PAs and STS is the least effective for organogenesis (Table 1 and 2). Ethylene produced by plant tissues grown in vitro may accumulate in large quantities in 
culture vessels, thus potentially affecting growth and development. This may be due to the role of silver ions in overcoming the action and metabolism of ethylene. Several studies support that ethylene affects callus growth and plant regeneration in vitro (Saiprasad and Raghuveer, 2007; Sarropoulou et al, 2016). Sridhar et al. (2011) reported that STS significantly increased the shoot regeneration response and average buds in Solanum nigrum. Similar to our results, the effect of SPD and induced a maximum shoot regeneration in gherkin (Thiruvengadam and Chung, 2015). However, the addition of SPD $\left(75 \mathrm{mgL}^{-1}\right)$ in MS containing STS $\left(10 \mathrm{mgL}^{-1}\right)$ produced a higher percentage of response as well as the number of shoots/ jar when compared to STS alone (Table 5). In Cucumis sativus (Vasudevan et al. 2008) and Withania somnifera (Sivanandhan and Salammal, 2011), SPD supplementation of the culture medium improved shoot regeneration compared to putrescine as observed in the current study Our results are in agreement with previously reported results showing the stimulative role of PAs or STS in organogenesis in many plants (Bader and Khierallah 2009; Park et al., 2012; Arun et al.,2014; Roh et al., 2015, Muhusen et al.,2020).

The number, length, and development of roots is essential factor in the in-vitro development of plants. PAs play a vital role in rooting. The effect of polyamines on the number, length and development of roots was studied. It was found that these factors depend on the type and concentration of polyamines and their combinations with STS. The highest response percentage and numbers of roots were obtained on the media supplemented with $75 \mathrm{mg} \mathrm{L}^{-1}$ PUT and $10 \mathrm{mg}$ $\mathrm{L}^{-1}$ STS. Although a high concentration of $150 \mathrm{mg} \mathrm{L}^{-1}$ PAs positively affects the length of roots compared to the other treatments, it has no significant effect on rooting percentage and the number of the roots. PAs are involved in various cellular and physiological pathways and cycles that promote root growth, proving an essential role in differentiation. PAs play a major role in cell division and different morphogenetic processes, including rooting (Kiełkowska and Adamus, 2021). Our results indicate that PUT improved rooting efficiency, whereas spermidine showed less response to root induction. Denaxa et al. (2014) reported that PUT improved the rooting response of difficult-to-root 'Kalamata' olive cultivar, compared with SPD, which failed to promote rooting. Endogenous PUT is considered a marker of root induction in vitro. Its catabolism could be the basis for root growth by providing $\mathrm{H}_{2} \mathrm{O}_{2}$ (Neves et al. 2002). It has previously been shown that PUT to MS media increases endogenous PUT accumulation to promote root induction and growth (Hausman et al. 1995). PUT also acts as a second messenger, correlating with the peak of root mitotic activity (Tiburcio et al. 1989). Similarly, PUT induced root induction in Pinus virginiana (Tang and Newton, 2005). The encouragement of palm plants during the rooting stage by STS may be due to the unique function of silver, which appears to be unique among the heavy metals that play an inhibitory role in ethylene biosynthesis. This result is in harmony with Sharaf et al. (2012), who reported a positive correlation between response to rooting and STS. Roh et al., (2012) reported that the medium supplemented with STS compound encouraged roots cultures to elongate and proliferate. Similar results were obtained by Harathi and Naidu, (2016), who suggested that adding ethylene inhibitor to the culture medium along with an auxin significantly augmented the induction of roots.

The acclimatization process is crucial in the micropropagation process of date palm plantlets. One of the main obstacles to applying micropropagation technology is the high mortality rate during transfer to the soil. PAs in general and PUT in particular are nitrogen sources that have an anti-stress influence on stressed plants (Chen et al., 2018). Ethylene produced by plant tissues grown in vitro may accumulate in large quantities in culture vessels, thus potentially affecting growth and development. The beneficial effect of STS depends on the function of silver ion acting as an ethylene antagonist (playing as an inhibitor of ethylene biosynthesis) (Sharaf et al.,2012).

Micropropagation cannot be considered completely successful unless complete genetic fidelity is maintained. The regenerated plants from tissue culture were checked for their genetic stability using RAPD primers. RAPD has been extensively used in genetic variation experiments in date palm plants derived from tissue culture (Saker et al. 2000; Moghaieb et al.,2011). Four primers were selected based on the amplified bands' quantity, quality, and reproducibility. All bands matched perfectly with the DNA of the field donor plant. The detected bands were $100 \%$ monomorphic, 
indicating that the use of PAs and the STS during micropropagation phases caused no variation in the tissue culturederived plants of this date palm genotype. (The resultant clones are true-to type of the selected genotype). PAs carry positive charges on nitrogen atoms; this helps electrostatic attraction between DNA, RNA, proteins, and phospholipids. Hence, PAs play a role in membrane fluidity, signal transduction, elicitation, RNA processing, chromatin remodelling, etc. (Baron and Stasolla, 2008). Shenoy and Vasil (1992) reported that micropropagation through explants containing organized meristem is generally associated with a low risk of genetic instability. The culture conditions used to achieve plant regeneration from tissue where meristems are already present are less aggressive than those usually needed to induce shoots from differentiation. This result is in agreement with that previously reported by El-Bahr et al., (2019). Our findings are in agreement with the study of Abdol vand et al., (2018), who reported that the molecular results demonstrated the genetic stability of in vitro derived date palm plants. The banding pattern analysis confirmed no somaclonal variation and, therefore, the reliability of the micropropagation protocol for producing authentic plantlets of date palm cv. Quntar on a mass scale.

\section{Conclusion}

This study provides an efficient in vitro propagation method by providing a protocol for producing genetically uniform plants. Our study indicated that SPD use in combination with STS plays a synergistic role in increasing multiple shoot regeneration from callus tissues of date palm cv. Quntar in vitro. Also, particular emphasis should be done on PUT, which in combination with STS, in the rooting medium, was essential in stimulating a high rooting percentage with high quality of roots, resulting in fast-growing plantlets during acclimatization phase, reaching $90 \%$ of plant survival. On the other hand, no genetic variation was observed by the four RAPD primers tested. The in vitro micropropagation protocol developed in this research can be used for the large-scale production of genetically stable date palm.cv. Quntar

\section{Abbreviations}

NAA

Naphthaleneacetic acid

IAA

Indoleacetic acid

2iP

N6-(2-Isopentenyl) adenine

PUT

Putrescine

SPD

Spermidine-

STS

Silver thiosulfate

\section{Declarations}

\section{ACKNOWLEDGEMENTS}

The author wishes to thank all the Date Palm Research Center staff, especially in the Date Palm propagation Lab.

Author contributions Al-Mayahi preparing the culture media and the conduct of plant tissue culture of the date palm, and the follow of the growth and development of cultures. The author also analyzed the physiological characteristics 
of the tissues and wrote the manuscript.

\section{Compliance with ethical standards}

Conflict of interest The author declares that he has no conflict of interest benefit.

\section{References}

1. Abdol VB, Zarghami R, Ari AA (2018) The effects of Agno3 and 2iP on a different stage of somatic embryogenic in date palm cv Medjool. Pak J Bot 50(2):495-502

2. Adawy SS, Hussein Ebtissam HA, Saker MM, El-Itriby Hanaiya A (2004) Intra- and Inter-varietal variation of Upper Egypt date palm cultivars (Phoenix dactylifera L.): I. As revealed by RAPD and Inter Simple Sequence Repeat markers. Proceed. Int. Conf. Genet. Eng. Appl. Sharm El-Sheikh, South Sinai, Egypt (April, 8-11, 2004): 165-179.

3. Al-Mayahi AMW (2010) The Effect of Amino Acids and Silver Nitrate in the Growth and Organogenesis of Adventitious Buds for Date Palm (Phoenix dactylifera L.) cv. Showaithy by in vitro. Damas Uni J Agril Sci 26(2):95-110

4. Al-Mayahi AMW (2016) Effect of red and blue light emitting diodes "CRB-LED" on in vitro organogenesis of date palm (Phoenix dactylifera L.) cv. Alshakr. World J Micro Biotech 32:160

5. Al-Mayahi AMW (2019) Effect of aluminium on the growth of the in vitro culture tissues of the date palm (Phoenix dactylifera L.) cv. Um-Adelhin Folia Oecol 46(2):164-169

6. Al-Mayahi AMW (2020) Effect of calcium and boron on growth and development of callus and shoot regeneration of date palm cv. Barhee Cana J Plant Sci 100(4):357-364

7. Al-Mayahi AMW (2021a) The effect of humic acid (HA) and zinc oxide nanoparticles (ZnO-NPS) on in vitro regeneration of date palm (Phoenix dactylifera L.) cv. Quntar. Plant Cell Tiss Organ Cult 145:445-456

8. Al-Mayahi AMW (2021b) In vitro plant regeneration system for date palm (Phoenix dactylifera L.): effect of chelated iron sources. J Genet Eng Biotechnol 19:83

9. Al-Mayahi AMW, Ali AH (2021) Effects of different types of gelling agents on in vitro organogenesis and some physicochemical properties of date palm buds, Showathy cv. Folia Oecol 48(1):110-117

10. Al-Mayahi AMW, Ali AH, Shareef HJ (2018) Influence of cold pretreatment on shoot regeneration from callus in date palm (Phoenix dactylifera L.) cv. 'Barhee'. J Gen Eng Biotech 16:607-612

11. Al-Mayahi AMW, Jafar ON, Mohsen KA (2020) Effect of glutathione (GSH) on Date palm (Phoenix dactylifera L.) micropropagation. Folia Oecol 47(1):64-69

12. Arun M, Subramanyam K, Theboral J, Ganapathi A, Manickavasagam M (2014) Optimized shoot regeneration for Indian soybean: The influence of exogenous polyamines. Plant Cell Tiss Organ Cult 117:305-309

13. Bader SM, Khierallah HS (2009) The Role of Silver Thiosulphate and Glutamine on Direct Organogenesis of Two Date Palm (Phoenix dactylifera L.) Cultivars. J Biotech Res Cen 3(1):37-45

14. Bais HP, Ravishankar GA (2002) Role of polyamines in the ontogeny of plants and their biotechnological applications. Plant Cell Tiss Org Cult 69:1-34

15. Baron K, Stasolla C (2008) The role of polyamines during in vivo and in vitro development. In Vitro Cell Dev Plant 44:384-395

16. Chae SC (2016) Shoot organogenesis of Echinacea angustifolia DC as influenced by polyamines.Life Sci J: 13(1)

17. Chaudhary DS, Kajla A, Poonia B, Brar S, Duhan JS (2015) Molecular assessment of genetic stability using ISSR and RAPD markers in commercial banana cultivar cv. Robusta India J Biotech 14(3):420-424 
18. Chen D, Shao Q, Yin L, Younis A, Zheng B (2019) Polyamine function in plants: Metabolism, regulation on development, and roles in abiotic stress responses. Front Plant Sci. 9, 1945

19. Couée I, Hummel I, Sulmon C, Gouesbet G, Amrani AE (2004) Involvement of polyamines in root development. Plant Cell Tissue Organ Cult 76:1-10

20. Denaxa NK, Roussos PA, Vemmos SN (2014) The possible role of polyamines to the recalcitrance of "Kalamata" olive leafy cuttings to root. J Plant Growth Regul 33:579-589

21. Devi SP, Kumaria S, Rao SR, Tandon P (2013) In vitro propagation and assessment of clonal fidelity of Nepenthes khasiana Hook. f.: a medicinal insectivorous plant of India. Acta Physiol Plant 35:2813-2820

22. Dey A, Hazra AK, Nongdam P, Nandy S, Tikendra L, Mukherjee A, Banerjee S, Mukherjee S, Pandey DK (2019) Enhanced bacoside content in polyamine treated in-vitro raised Bacopa monnieri (L.) Wettst. S Afr J Bot 123:259269

23. El-Bahr MK, El-Ashry AAE, Gabr AMM (2019) Impact of Antioxidants on in vitro Rooting and Acclimatization of Two Egyptian Dry Date Palm Cultivars. PAK J Biol Sci 22:435-443

24. Harathi K, Naidu CV (2016) Influence of Ethylene Inhibitor Silver Nitrate on Direct Shoot Regeneration from in Vitro Raised Shoot Tip Explants of Sphaeranthus indicus Linn. An Important Antijaundice Medicinal Plant. Amer J Plant Sci 7:525-532

25. Hausman JF, Kevers C, Gaspar T (1995) Auxin-polyamine interaction in the control of the rooting inductive phase of poplar shoots in vitro. Plant Sci 110:63-71

26. Ibrahim MA, Waheed AM, Al-Taha H, Al-Taha H (2013) Plantlet regeneration from root segments of Date palm tree (Phoenix dactylifera L. cv.Barhee) producing by in vitro culture. AAB BIOFLUXAAB Bioflux 5(1):45-50

27. levinsh G, Kruzmane D, Rusite E, Arente G, Gertnere D (2000) Modulation of Solanum tuberosum L. morphogenesis and antioxidative status in a stem explant culture by limitation of gas exchange: putative effects of ethylene. J Plant Physi 156(5-6):717-723

28. Kiełkowska A, Adamus A (2021) Exogenously Applied Polyamines Reduce Reactive Oxygen Species, Enhancing Cell Division and the Shoot Regeneration from Brassica oleracea L. var. capitata Protoplasts. Agronomy 11:735

29. Mattoo AK, Minoscha SC, Minocha R, Handa A (2010) Polyamines and cellular metabolism in plants: transgenic approaches reveal different responses to diamine putrescine versus higher polyamines spermidine and spermine. Amino Acids 38:405-413

30. Moghaieb REA, Abdel-Hadi AA, Ahmed MRA (2011) ) Genetic stability among date palm plantlets regenerated from petiole explants. Afri J Biotech 10(65):14311-14318

31. Muhusen KA, Hantosh EA, Darweash MA (2020) The effect of puterscine and sal salic acid and their interaction on the multiplication of vegetative bud and their characteristics for date palm cultivar Al-Barhi in vitro. Plant Cell Biotech Molec Biology 21(1920):112-125

32. Murashige T, Skoog F (1962) A revised medium for rapid growth and bioassay with tobacco tissue cultures. Physiol. Plant. 15, 473Đ497

33. Nei M (1978) Estimation of average heterozygosity and genetic distance from a small number of individuals. Genetic 89:583-590

34. Neves C, Santos H, Vilas-Boas L, Amâncio S (2002) Involvement of free and conjugated polyamines and free amino acids in the adventitious rooting of micropropagated cork oak and grapevine shoots. Plant Physiol Biochem 40:1071-1080

35. Othmani A, Rhouma S, Bayoudh C, Mzid R, Drira N, Trifi M (2010) Regeneration and analysis of genetic stability of plantlets as revealed by RAPD and AFLP markers in date palm (Phoenix dactylifera L.) cv. Deglet Nour. Int Res J

Page 10/19 
Plant Sci 1(3):48-55

36. Park E, Bae H, Park WT, Kim YB, Chae SC, Park SU (2012) Improved shoot organogenesis of gloxinia (Sinningia Speciosa) using silver nitrate and putrescine treatment. Plant Omics J 5:6-9

37. Rakesh B, Sudheer WN, Nagella P (2021) Role of polyamines in plant tissue culture: An overview. Plant Cell Tiss Organ Cult

38. Rogers SO, Bendich AJ (1985) Extraction of DNA from milligram amounts of fresh, herbarium and mummified plant tissues. Plant Mol Biol 5:69-76

39. Roh KH, Kwak BK, Kim JB, Lee KR, Kim HU, Kim SH (2012) The influence of silver thiosulfate and thidiazuron on shoot regeneration from cotyledon explants of Brassica napus. J Plant Biotechnol 39:133-139

40. Saiprasad GVS, Raghuveer P (2007) Influence of ethylene inhibitors and ethrel on production of protocorm like bodies in orchid -. Dendrobium 'Sonia' J Hort Sci 2(1):13-18

41. Saker MM, Bekheet SA, Taha HS, Fahmy AS, Moursy HA (2000) Detection of somaclonal variations in tissue culture-derived date palm plants using isoenzyme analysis and RAPD fingerprints. Biol Plant 43:347-351

42. Srivashtav VS, Kapadia CV, Mahatma MK, Jha SK, Jha S, Ahmad T (2013) Genetic diversity analysis of date palm (Phoenix dactylifera L.) in the Kutch region of India using RAPD and ISSR markers. Emi J Food Agri 25(11):907915

43. Takahashi T, Kakehi J (2010) Polyamines: ubiquitous polycations with unique roles in growth and stress responses. Annals Bot 105(1):1-6

44. Tamimi SM (2015) Effects of ethylene inhibitors, silver nitrate (AgNO3), cobalt chloride (CoCl2) and aminooxyacetic acid (AOA), on in vitro shoot induction and rooting of banana (Musa acuminata L.). Afr J Biotechnol 14(32):2510-2516

45. Tang W, Newton R (2005) Polyamines promote root elongation and growth by increasing root cell division in regenerated Virginia pine (Pinus virginiana Mill.) plantlets. Plant Cell Rep 24(10):581-589

46. Thiruvengadam M, Chung M (2015) Phenolic compound production and biological activities from in vitro regenerated plants of gherkin (Cucumis anguria L.). Elect J Biotech 18:295-301

47. Thiruvengadam $M$, Chung $M$, Chul Chun S (2012) Influence of polyamines on in vitro organogenesis in bitter melon (Momordica charantia L.). J Med Plants Res 6(19):3579-3585

48. Thorpe TA (2007) History of Plant Tissue Culture. Molec Biotech 318:9-32

49. Tiburcio A, AltabellaT, Bitrián M, Alcázar R (2014) The roles of polyamines during the lifespan of plants: from development to stress. Planta 240(1):1-18

50. Tiburcio AF, Gendy CA, Van TT (1989) Morphogenesis in tobacco subepidermal cells: putrescine as marker of root differentiation. Plant Cell Tissue Organ Cult 19:43-54

51. Sarropoulou V, Dimassi-theriooou K, Therios I (2016) Effect of the ethylene inhibitors silver nitrate, silver sulfate, and cobalt chloride on micropropagation and biochemical parameters in the cherry rootstocks CAB-6P and Gisela 6. Turk J Biol 40:670-683

52. Sharaf MM, Khamis MA, El-Bana A, Abd El-Galeil LM, Zaid ZE (2012) Improvement of date palm plantlets during rooting stage.by silver ion. Third International Conference on Radiation Sciences and Applications. 709-719

53. Shenoy VB, Vasil IK (1992) Biochemical and molecular analysis of plants derived from embryogenic tissue cultures of napiergrass (Penisetum purpureum K. Schum.). Theor Appl Genet 83:947-955

54. Sivanandhan G, Salammal T (2011) The effect of polyamines on the efficiency of multiplication and rooting of Withania somnifera (L.) Dunal and content of some withanolides in obtained plants. Acta Physiol Plant 33:22792288

Page $11 / 19$ 
55. Sridhar TM, Preethi D, Naidu CV (2011) Effect of silver thiosulphate on in vitro plant regeneration of Solanum nigrum (Linn.) An important antiulcer medicinal plant. Current Botany 2:14-16

56. Vasudevan A, Selvaraj N, Ganapathi A, Kasthurirengan S, Ramesh-Anbazhagan V, Manickavasagam M, Choi C (2008) Leucine and spermidine enhance shoot differentiation in cucumber (Cucumis sativus L.). In Vitr. Cell Dev Biol Plant 44:300-306

57. Wang KL, Li H, Ecker JR (2002) Ethylene biosynthesis and signaling networks. Plant Cell 14:131-151

\section{Tables}

Due to technical limitations, tables 1,2 , and 5 are only available as downloads in the Supplemental Files section.

Table 3. The RAPD primers and their sequences used for the genetic fidelity evaluation

\begin{tabular}{|ll|}
\hline Primers & Sequences \\
\hline OPA02 & TGCCGAGCTG3 \\
\hline OPC 04 & CCGCATCTAC \\
\hline OPD 07 & TTGGCACGGG \\
\hline OPE-15 & ACGCACAACC \\
\hline
\end{tabular}

Table 4. Effect of polyamines on the response percentage of callus for bud formation and a number of shoots after 12 wk of culturing for date palm, cv Quntar.

\begin{tabular}{|c|c|c|}
\hline Polyamines treatments $\left(\mathrm{mg} \mathrm{L}^{-1}\right)$ & Response of callus for shoot formation & $\begin{array}{l}\text { Number of } \\
\text { shoots }\end{array}$ \\
\hline Control & $26.67 \pm 3.89$ & $2.75 \pm 0.22$ \\
\hline 25 PUT & $33.34 \pm 3.05$ & $3.50 \pm 0.40$ \\
\hline 75 PUT & $60.00 \pm 4.70$ & $7.66 \pm 0.58$ \\
\hline 150 PUT & $40.00 \pm 3.06$ & $4.33 \pm 0.42$ \\
\hline 25 SPD & $40.00 \pm 3.06$ & $3.83 \pm 0.50$ \\
\hline 75 SPD & $73.34 \pm 4.60$ & $9.18 \pm 0.21$ \\
\hline 150 SPD & $46.67 \pm 3.89$ & $4.71 \pm 0.60$ \\
\hline LSD<0.05 & 13.33 & 1.10 \\
\hline
\end{tabular}

\pm Standard error (n15).

Table 6 Effect of polyamines on rooting of shoots date palm cv Quntar after six weeks of culture 


\begin{tabular}{|c|c|c|c|}
\hline Polyamines treatments $\left(\mathrm{mg} \mathrm{L}^{-1}\right)$ & $\begin{array}{l}\text { Response of shoot for root } \\
\text { Formation (\%) }\end{array}$ & $\begin{array}{l}\text { Number of } \\
\text { roots }\end{array}$ & Lengths of roots \\
\hline Control & 20 & $2.00 \pm 0.30$ & $2.3 \pm 0.42$ \\
\hline 25 PUT & 40 & $4.25 \pm 0.42$ & $3.6 \pm 0.70$ \\
\hline 75 PUT & 80 & $5.75 \pm 0.10$ & $4.9 \pm 0.20$ \\
\hline 150 PUT & 30 & $2.66 \pm 0.32$ & $5.2 \pm 0.60$ \\
\hline 25 SPD & 30 & $3.34 \pm 0.20$ & $3.0 \pm 0.17$ \\
\hline 75 SPD & 60 & $4.66 \pm 0.20$ & $4.1 \pm 0.42$ \\
\hline 150 SPD & 20 & $2.50 \pm 0.42$ & $4.4 \pm 0.37$ \\
\hline LSD $<0.05$ & 19.9 & 0.35 & 0.6 \\
\hline
\end{tabular}

$*_{ \pm}$Standard error $(n=10)$

Table 7 Effect of putrescine "PUT" and silver thiosulfate (STS) on a response percentage (\%) of shoots for root formation and a number of roots/shoot for date palm, cv. Quntar.

\begin{tabular}{|c|c|c|c|c|c|c|c|}
\hline $\begin{array}{l}\text { Treatments } \\
\left(\mathrm{mgL}^{-1}\right)\end{array}$ & Frequency [\%] & $\begin{array}{l}\text { Root } \\
\text { number }\end{array}$ & $\begin{array}{l}\text { Root } \\
\text { leanth } \\
\text { (cm) }\end{array}$ & $\begin{array}{l}\text { Treatments } \\
\left(\mathrm{mgL}^{-1}\right)\end{array}$ & Frequency [\%] & $\begin{array}{l}\text { Root } \\
\text { number }\end{array}$ & $\begin{array}{l}\text { Root } \\
\text { leanth } \\
\text { (cm) }\end{array}$ \\
\hline $\begin{array}{l}\text { 0.0 PUT + +5 } \\
\text { STS }\end{array}$ & $16.67 \pm 1.53$ & $\begin{array}{l}2.50 \\
\pm 0.25\end{array}$ & $\begin{array}{l}2.30 \pm \\
0.42\end{array}$ & $\begin{array}{l}75 \text { PUT }+10 \\
\text { STS }\end{array}$ & $91.67 \pm 6.40$ & $6.37 \pm 0.40$ & $\begin{array}{l}5.9 \pm \\
0.80\end{array}$ \\
\hline $\begin{array}{l}25 \text { PUT + } 5 \\
\text { STS }\end{array}$ & $41.67 \pm 3.89$ & $3.80 \pm 0.50$ & $3.50 \pm 0.50$ & $\begin{array}{l}150 \text { PUT } \\
+10 \text { STS }\end{array}$ & $33.34 \pm 2.06$ & $3.25 \pm 0.40$ & $6.1 \pm 0.40$ \\
\hline $\begin{array}{l}75 \text { PUT + } 5 \\
\text { STS }\end{array}$ & $75.00 \pm 3.37$ & $5.56 \pm 0.20$ & $4.80 \pm 0.20$ & $\begin{array}{l}0.0 \text { PUT + } \\
15 \text { STS }\end{array}$ & $8.34 \pm 0.81$ & $2.00 \pm 0.30$ & $\begin{array}{l}2.1 \pm \\
0.09\end{array}$ \\
\hline $\begin{array}{l}150 \text { PUT +5 } \\
\text { STS }\end{array}$ & $25.00 \pm 3.89$ & $3.00 \pm 0.20$ & $5.11 \pm 0.60$ & $\begin{array}{l}25 \text { PUT +15 } \\
\text { STS }\end{array}$ & $33.34 \pm 2.06$ & $3.50 \pm 0.40$ & $2.9 \pm 0.20$ \\
\hline $\begin{array}{l}0.0 \text { PUT }+10 \\
\text { STS }\end{array}$ & $25.00 \pm 3.89$ & $2.66 \pm 0.40$ & $\begin{array}{l}2.50 \pm \\
0.25\end{array}$ & $\begin{array}{l}75 \text { PUT }+15 \\
\text { STS }\end{array}$ & $58.34 \pm 4.81$ & $4.70 \pm 0.42$ & $3.2 \pm 0.10$ \\
\hline $\begin{array}{l}25 \text { PUT +10 } \\
\text { STS }\end{array}$ & $50.00 \pm 2.75$ & $4.16 \pm 0.37$ & $4.10 \pm 0.50$ & $\begin{array}{l}150 \text { PUT } \\
+15 \text { STS }\end{array}$ & $16.67 \pm 1.53$ & $\begin{array}{l}2.50 \pm \\
0.25\end{array}$ & $\begin{array}{l}4.3 \pm \\
0.42\end{array}$ \\
\hline LSD $<0.05$ & 13.90 & 0.70 & 1.20 & LSD $<0.05$ & 13.90 & 0.70 & 1.20 \\
\hline
\end{tabular}

$\star \pm$ Standard error $(n=12)$

\section{Figures}



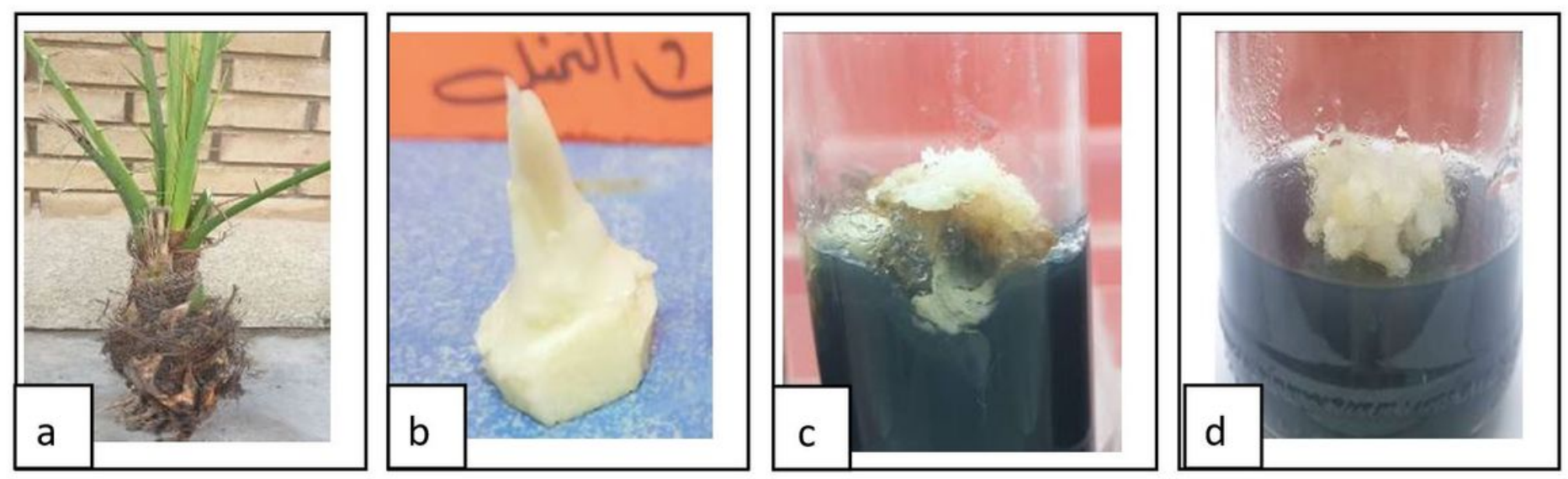

\section{Figure 1}

Induction of callus of date palm (P. dactylifera L. cv. Quntar) from apical buds of offshoot: a) Offshoot; b) Apical bud, c) Apical development; d) Callus formation. 

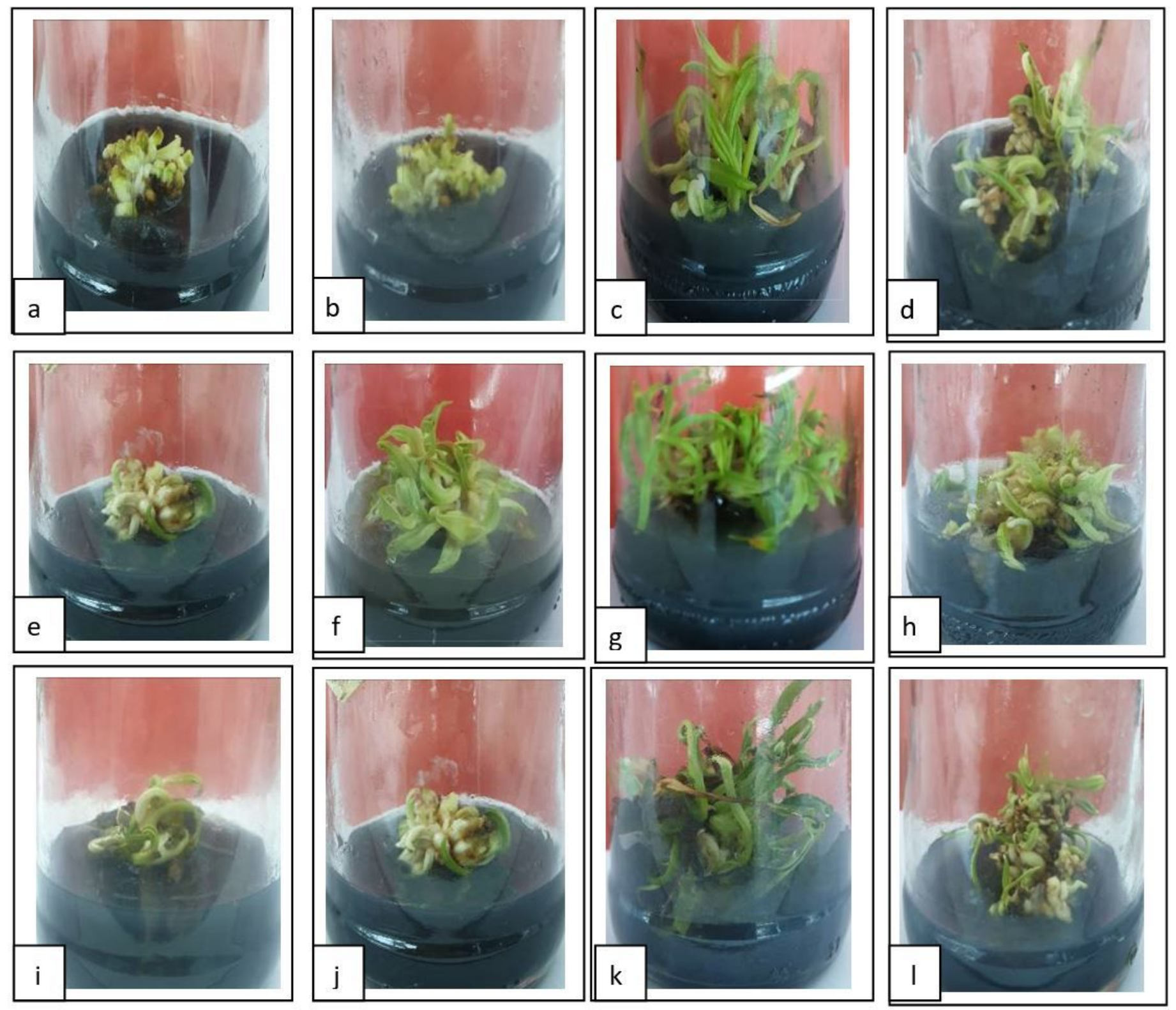

\section{Figure 2}

Bud induction on MS media supplemented with polyamines (PAS) and silver thiosulfate (STS) (mg. $\mathrm{L}^{-1}$ ) of date palm cv Quntar: a control, b 0.0 SPD +5 STS, c 25 SPD + 5 STS, d 75 SPD +5 STS, e 150 SPD +5 STS, f 0.0 SPD+10 STS , g 25 SPD+10 STS, h 75 SPD+10 STS. i 150 SPD +10 STS + 0.0 SPD + 15 STS, j 25 SPD +15 STS, k 75 SPD+15 STS, I 150 SPD+ 15 STS. 

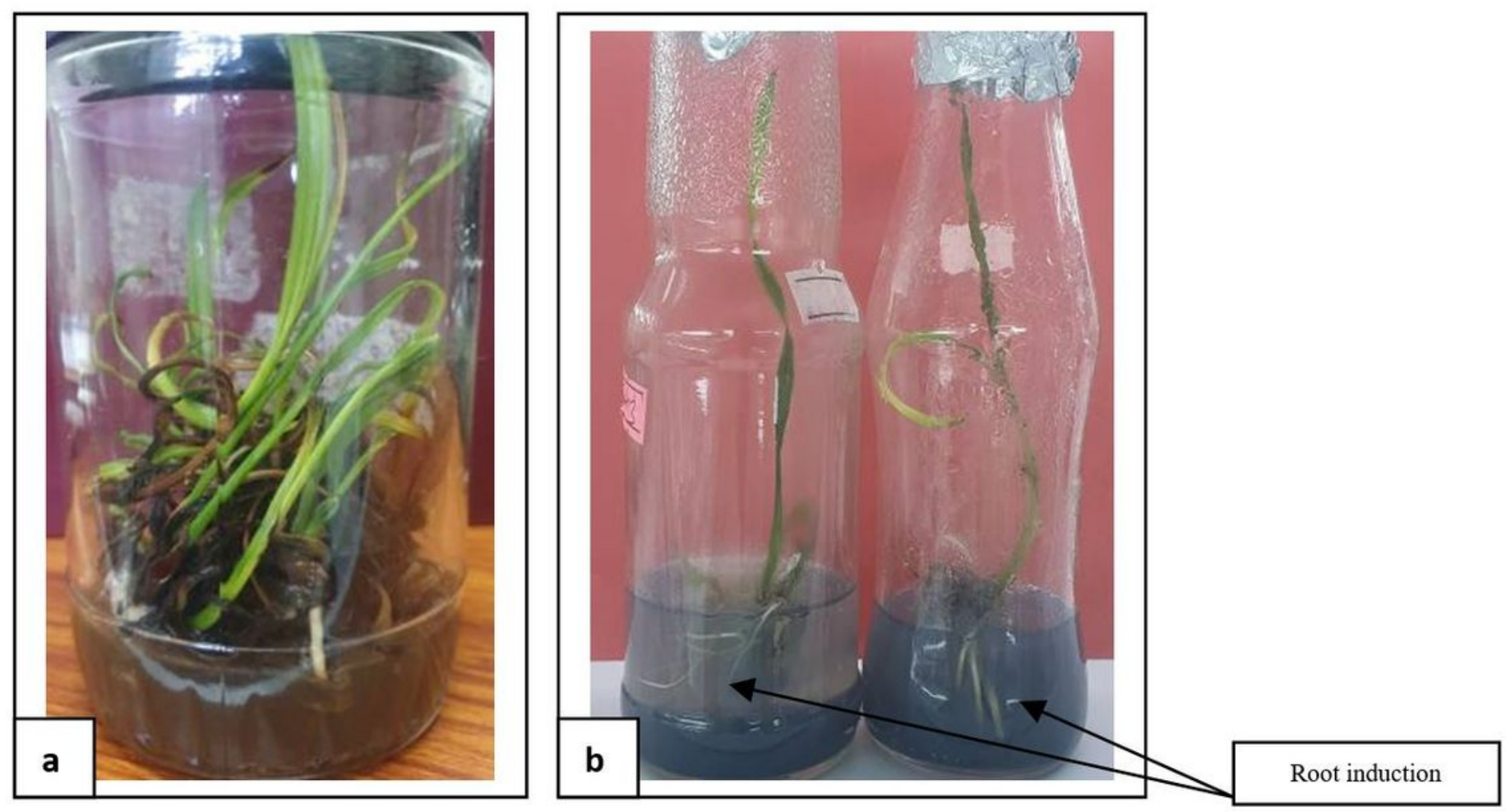

Figure 3

Rooting of date palm shoots cv. Quntar: a) Separation of the shoots; b) Roots formation in MS medium supplied with $75 \mathrm{mg} \mathrm{L}^{-1}$ PUT in combination with $10 \mathrm{mg} \mathrm{L}^{-1}$ STS, after 45 days from shoots culture on the rooting medium. 


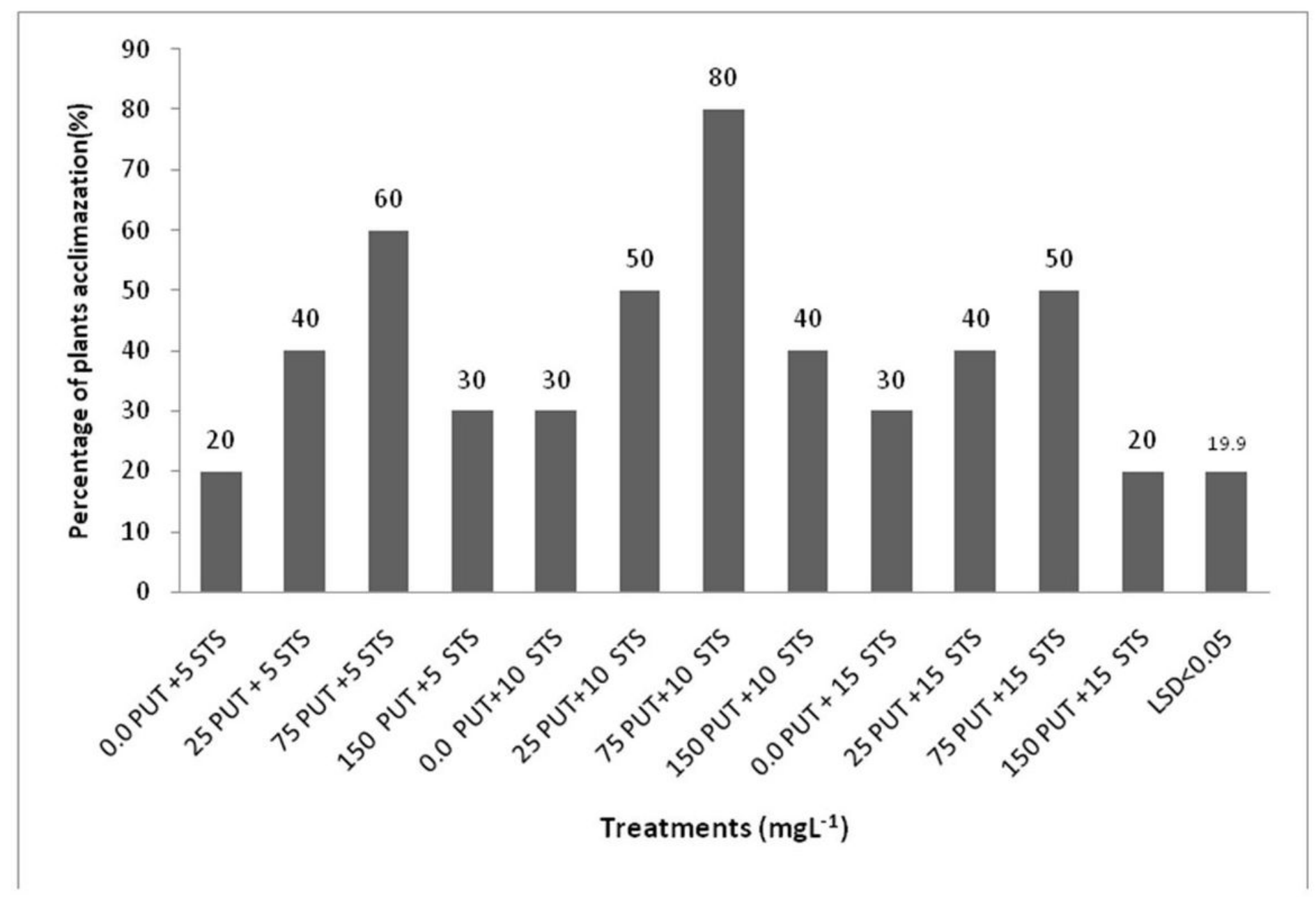

Figure 4

Effect of PUT and STS on acclimatization of date palm cv. Quntar after eight weeks of culture in plastic pots.
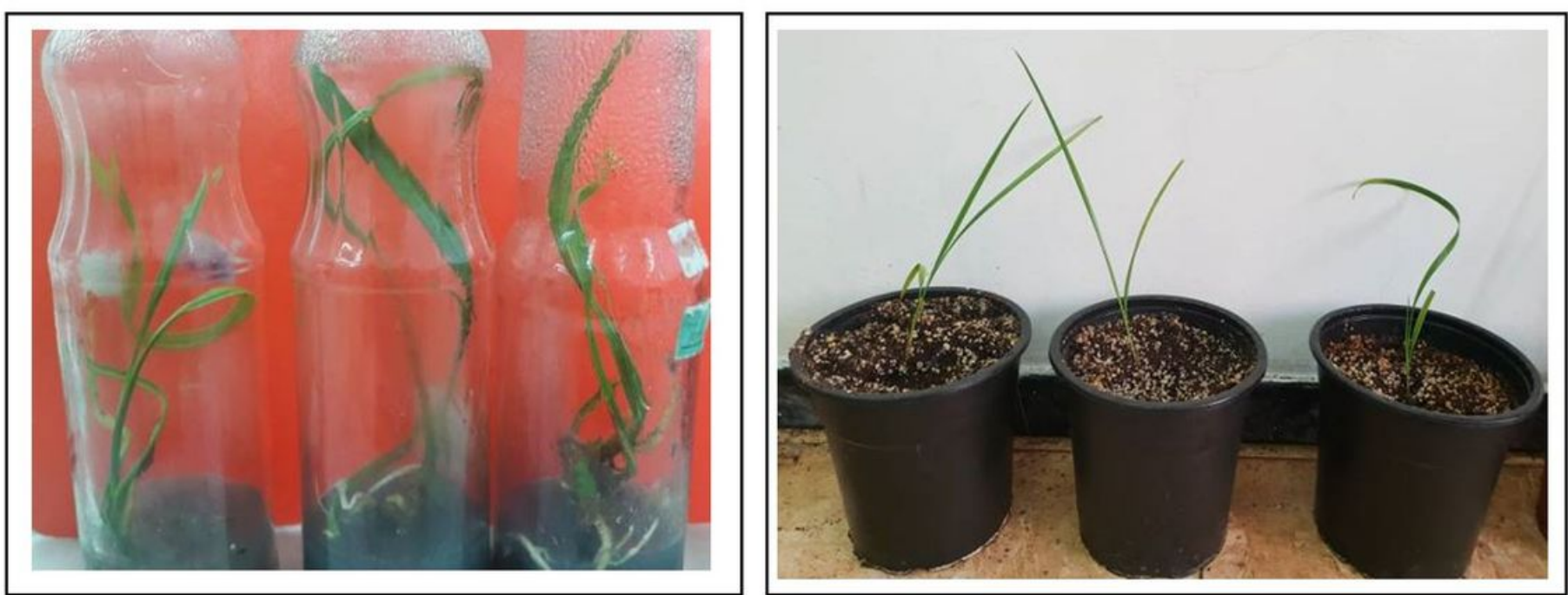


\section{Figure 5}

Date palm plants eight weeks after transfer from media containing $75 \mathrm{mg} \mathrm{L}^{-1}$ PUT with $10 \mathrm{mg} \mathrm{L}^{-1}$ STS to plastic pots.
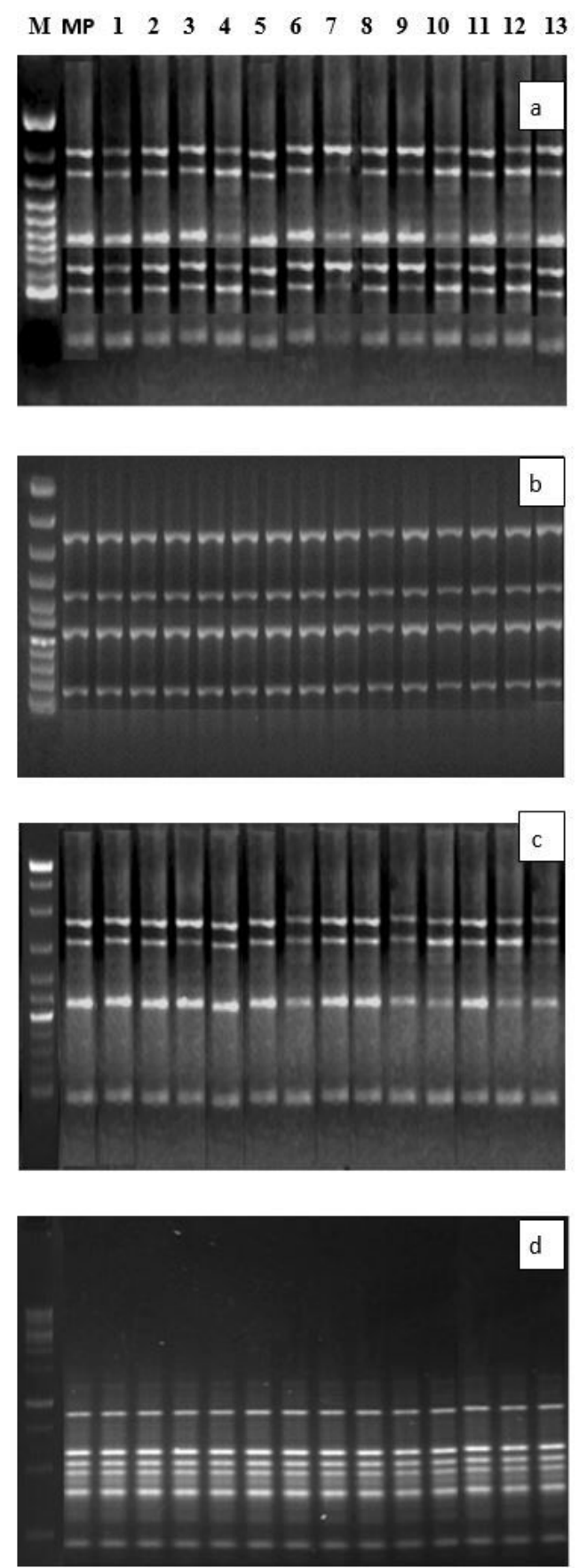

\section{Figure 6}

(a- OPA02, b- OPC-04, c- OPD-07 and d- OPE-15). RAPD pattern of regenerated plants of Phoenix dactylifera L. cv Quntar on MS medium supplemented with putrescine (PUT) in combination with silver thiosulfate (STS) (mgL-1): (M) Size marker (1) MP: Mother Plant, (2) 0.0 PUT+5 STS, (3) 25 PUT+ 5 STS, (4) 75 PUT+5 STS, (5) 150 PUT+5 STS, (6) 0.0 PUT+10 STS , (7) 25 PUT+10 STS; (8) 75 PUT+10 STS. (9) 150 PUT+10 STS (10) 0.0 PUT+15 STS, (11) 25 PUT+15 STS, (12) 75 PUT+15 STS (13) 150 PUT+15 STS. 


\section{Supplementary Files}

This is a list of supplementary files associated with this preprint. Click to download.

- Table1.jpg

- Table2.jpg

- Table5.jpg 